\title{
Studies on some biochemical constituents of mithun
}

\section{semen}

\begin{abstract}
A total of 15 semen samples were collected from 3 Mithun bulls reared at the farm of National Research Centre on Mithun (NRCM), Nagaland to measure cholesterol (mg/ $\mathrm{dl})$, total protein $(\mathrm{g} / \mathrm{dl})$, glutamic oxaloacetic transaminase (IU/ L), glutamic pyruvic transaminase (IU/ L), lactic dehydrogenase (IU/ L), glucose $(\mathrm{mg} / \mathrm{dl})$, sodium $(\mathrm{mmol} / \mathrm{L})$ and potassium $(\mathrm{mmol} / \mathrm{L})$ and their mean concentrations were recorded as $23.94 \pm 6.37$, $3.57 \pm 0.64, \quad 31.61 \pm 7.30, \quad 15.58 \pm 1.50, \quad 78.36 \pm 6.46, \quad 32.57 \pm 9.78, \quad 300.30 \pm 40.30$ and $16.05 \pm 1.30$, respectively.
\end{abstract}

Keywords: seminal constituents, mithun, male reproduction
Volume 2 Issue 6 - 2015

\author{
Bhattacharyya HK,' Goswami BK,' \\ Bujarbaruah KM,' Deka BC, ${ }^{2}$ Biswas RK² \\ 'Assam Agricultural University, India \\ ${ }^{2}$ Department of Gynecology and Obstetrics, Assam Agricultural \\ University, India
}

\begin{abstract}
Correspondence: Hiranya Kumar Bhattacharyya, Senior Scientist, Krishi Vigyan Kendra (Farm Science Centre), Assam Agricultural University (AAU), P.O. Lahoal, Post Box No: 24, Dibrugarh-7860I0,Assam, India, Tel +9l 943556 439I, Email drhiranyabh@yahoo.co.in
\end{abstract}

Received: October 15, 2015 | Published: November 6, 2015

\section{Introduction}

The Mithun (Bos frontalis), a semi-wild animal, which is yet to be fully domesticated, is mainly confined in India, Bhutan, Myanmar, Bangladesh and hilly tracts of China and Malaysia. In India it is only found in the hilly tracts of four states of North Eastern India namely Arunachal Pradesh, Nagaland, Manipur and Mizoram, in descending order of population. Mithun plays a significantly important role in the socio-economic and religious life of the people of this region living at an altitude of $2700-3000$ meter above sea level. ${ }^{1}$ It is very much important to know the biochemical constituents of seminal plasma of normal bulls as any alterations in its normal concentration may reflect some abnormalities in genital system. Moreover it will help in conducting future research activities related to semen processing and conservation. Till date no report is available on biochemical constituents of Mithun semen. In our earlier papers we described detailed collection procedure and characterization of semen collected by both massage and artificial vagina method in Mithun bulls. ${ }^{2,3}$ Now, we wish to report on some seminal biochemical constituents, in this valuable animal species.

\section{Materials and methods}

Semen samples (15no's) were collected from 3Mithun bulls (5 samples from each bull), aged 2.5 to 4years, maintained at the farm of National Research Centre on Mithun (NRCM), Nagaland, along with other Mithun of the herd purchased few months earlier from different hilly tracts of North-Eastern states of India. The bulls were maintained under semi-intensive system of management providing concentrate feed in the morning and evening and allow them to graze in the intervening period. The bulls were giving training for semen collection for few months before they were actually used for semen collection using both estrous and anestrous female as teaser. Semen was collected with the help of artificial vagina having an internal temperature of $42^{\circ} \mathrm{C}$ and $46^{\circ} \mathrm{C}$ (average $44^{\circ} \mathrm{C}$ ), using estrous female as teaser, whenever available in the herd, ${ }^{3}$ as bulls did not mount anestrous female. Within an hour of collection of semen, seminal plasma was removed by centrifuging semen at 3000rpm for 30minutes. Cholesterol (Ch), total protein (TP), glutamic oxaloacetic transaminase (GOT), glutamic pyruvic transaminase (GPT), lactic dehydrogenase (LDH), glucose, sodium (Na) and potassium (K) were estimated by standard calorimetric method in blood chemistry analyzer (RA-50 machine manufactured by Bayer Diagnostic, Bombay, India) using commercially available kit by the instructions provided in the leaflet supplied inside the kit. Finally $\mathrm{F}$ test was used to determine bull variations, if any, amongst the different biochemical constituents.

\section{Results and discussion}

The mean values of Cholesterol $(\mathrm{mg} / \mathrm{dl}), \mathrm{TP}(\mathrm{g} / \mathrm{dl}), \mathrm{GOT}(\mathrm{U} / \mathrm{L})$, GPT(U/L), LDH(U/L), glucose ( $\mathrm{mg} / \mathrm{dl}), \mathrm{Na}(\mathrm{mmol} / \mathrm{L})$ and $\mathrm{K}(\mathrm{mmol} / \mathrm{L})$ were recorded as $23.94 \pm 6.37,3.57 \pm 0.64,31.61 \pm 7.30,15.58 \pm 1.50$, $78.36 \pm 6.46,32.57 \pm 9.78,300.30 \pm 40.30$ and $16.05 \pm 1.30$, respectively (Table 1).

The mean values of cholesterol recorded in Mithun semen were lower than the values recorded for cattle, buffalo ${ }^{4,5}$ and goat semen. ${ }^{6}$ This might be due to the species variation.

The present finding with respect to TP simulates the finding of Ezekwe \& $\mathrm{Orzi}^{7}$ in domestic bulls. However, the value recorded in the present study was much higher than the values recorded by Buruiana et al., ${ }^{8}$ and lesser than the values recorded by Nafornita et al. ${ }^{9}$ in domestic cow bulls.

The mean level of GOT recorded in Mithun semen was higher than that reported in domestic bulls. ${ }^{10,11}$ Some earlier reports indicated much higher level of GOT content in domestic bull semen. ${ }^{8,9,12}$ The GPT value recorded in the study was in agreement with one report in domestic bulls. ${ }^{9}$ However, lower ${ }^{11}$ and higher ${ }^{10,12}$ values were also reported in domestic bulls. In the present study, GOT level was found to be higher than GPT level and the ratio was almost 2:1. Earlier workers also recorded higher GOT level than GPT level in bull semen. ${ }^{12,13}$ The LDH level recorded in Mithun semen was lower than the values recorded in Holstein Friesian ${ }^{11}$ and Punganur bull. ${ }^{14}$ In bulls, all these 
three enzymes are correlated with several factors including species, sperm concentration, sperm motility, live and dead sperm count, percent abnormal spermatozoa etc and their increased concentration in seminal plasma reflects spermatozoal damage. ${ }^{14}$ In Mithun, average sperm concentration $(\operatorname{million} / \mathrm{mL})$, initial sperm motility (\%), live sperm count $(\%)$ and percent abnormal spermatozoa( $\%)$ were recorded as $710.8 \pm 66.90,78.6 \pm 2.60,80.7 \pm 2.20$ and $80.6 \pm 0.2$, respectively. ${ }^{3}$

In the present study sodium content was found much higher than the potassium content. This simulates the earlier finding in cow bull's seminal plasma that sodium is in excess of potassium. ${ }^{15}$
The GPT, LDH, Glucose and K content was significantly varied between the three Mithun bulls; but, bull variation was not observed among the other constituents of seminal plasma. This may be due to species and or individual variation only. However, future research is required to know much on these aspects and also to have some other possible explanation for getting such discrepancies of biochemical constituents found in individual Mithun bulls.

Different biochemical constituents of Mithun semen were generally within the range reported for fertile domestic cow bulls and hence it is concluded that Mithun semen has the potential to result in fertile mating through artificial insemination too.

Table I Animal variations with respect to constituents of seminal plasma in Mithun

\begin{tabular}{|c|c|c|c|c|c|c|}
\hline Parameters & Animal I & Animal 2 & Animal 3 & Overall & F-value & Sig \\
\hline Cholesterol(mg/dl) & $22.15 \pm 15.19$ & $40.93 \pm 11.53$ & $12.53 \pm 2.58$ & $23.94 \pm 6.37$ & 2.161 & 0.186 \\
\hline Total Protein(g/dl) & $4.63 \pm 0.48$ & $4.23 \pm 0.54$ & $2.29 \pm 1.38$ & $3.57 \pm 0.64$ & 1.523 & 0.282 \\
\hline GOT(IU/L) & $25.91 \pm 8.08$ & $51.99 \pm 18.32$ & $20.6 I \pm 6.83$ & $31.61 \pm 7.30$ & 2.157 & 0.186 \\
\hline LDH(IU/L) & $66 .|4 \pm 4.0|^{a}$ & $61.32 \pm 1.64^{\mathrm{a}}$ & $|00.3| \pm 5.70^{b}$ & $78.36 \pm 6.45$ & 22.587 & $0.001 *$ \\
\hline Glucose(mg/dl) & $14.23 \pm 3.39^{a}$ & $69.09 \pm 7.28^{b}$ & $23.56 \pm 0.59^{a}$ & $32.57 \pm 9.78$ & 43.721 & $0.002 *$ \\
\hline $\mathrm{Na}(\mathrm{mmol} / \mathrm{L})$ & $383.64 \pm 16.43$ & $238.30 \pm 26.92$ & $237.30 \pm 119.73$ & $300.30 \pm 40.30$ & 2.298 & 0.217 \\
\hline $\mathrm{K}(\mathrm{mmol} / \mathrm{L})$ & $13.33 \pm 0.73^{a}$ & $21.20 \pm 2.00^{\mathrm{b}}$ & $15.33 \pm 1.053^{\mathrm{a}}$ & $16.05 \pm 1.30$ & 10.786 & $0.015 *$ \\
\hline
\end{tabular}

\section{Acknowledgements}

None.

\section{Conflict of interest}

Author declares that there is no conflict of interest.

\section{References}

1. Bhattacharyya HK, Islam Rafiqul, Bujarbaruah KM. Mithun: a unique ruminant of north-eastern India. Livestock International. $2005 ; 9(2): 22-23$

2. Bhattacharyya HK, Bujarbaruah KM, Goswami BK, et al. A trial of semen collection by massage method in Mithun (Bos frontalis) bulls. Indian Journal of Animal Sciences. 2006;76(11):905-906.

3. Bhattacharyya HK, Goswami BK, Bujarbaruah KM, et al. Collection and characterization of semen in Mithun (Bos frontalis) bulls. Theriogenology. 2009;72(5):699-703

4. Prabhu GA, Deshpande AD, Kodagali SB. Total cholesterol content in the seminal plasma of Kankrej cattle and Surti buffalo. Gujarat College of Veterinary Science and Animal Husbandry Magazine. 1973;6:16-19.

5. Choudhary KC, Gangwar PC. A note on seminal variations in the lipid constituents of buffalo (Bubalus bubalis) semen. Indian Journal of Animal Sciences. 1979;49(6):474-477.

6. Varshney VP, Sengupta BP, Pandey MD. A note on some chemica constituents of goat semen. Indian Journal of Animal Sciences. 1977;47(7):427-429.

7. Ezekwe AG, Orzi BJ. A comparative study in seminal biochemistry in N'Dama (Bos taurus) and Muturu (Bos brachyceros) bulls. Bulletin Animal Health Production in Africa. 1988;36(2):180-184.

8. Buruiana LM, Hadarag E, Petculescu M, et al. Biochemical changes in frozen bull semen. Lucari-Stiintifice Institutul-Agronomic- $N$-BalacescuD-Zootechnie. 1975;18:45-46.

9. Nafornita M, Rosu M, Opera I, et al. Some physical and chemical values and the activity of some enzymes in bull semen in winter. Lucari-Sintifice Institutul Agronomic Timisoara Medicina Veterinara. 1977;14:227-231

10. Saxena VB, Tripathi SS. A study of correlation and regression coefficients of bovine semen characteristics and preservability. Indian Journal of Animal Health. 1980;19(1):1-6.

11. Verma RP, Charan K, Mohan G. Comparative studies on blood and seminal plasma constituents of bovine. Indian Veterinary Medical Journal. 1988;12(1):47-48.

12. Singal SP, Kaker ML, Razdan MN. A note on enzymatic activity of semen transaminases in crossbred bulls. Haryana Agricultural University Journal of Research. 1976;6:164-166.

13. Chauhan RAS, Srivastava RK. Enzyme composition of buffalo seminal plasma. J Reprod Fert. 1973;34:165-166.

14. Rao KB, Naidu KV, Vijaya Singh Rao AS, et al. Studies on some enzymes level and their extracellular leakage during preservation of Punganur bulls semen. Indian Journal of Animal Reproduction. 1999;20(1):47-50

15. Cragle RG, Salisbury GW, Muntz JH. Distribution of bulk and trace minerals in bull reproductive tract fluids and semen. Dairy science. 1958;41(9):1273-1277. 